\title{
Bacillus thuringiensis isolates entomopathogenic for Culex quinquefasciatus (Diptera: Culicidae) and Anticarsia gemmatalis (Lepidoptera: Noctuidae)
}

\author{
Gobatto, V. ${ }^{\mathrm{a}}$, Giani, SG. ${ }^{\mathrm{a}}$, Camassola, M..$^{\mathrm{a}}$, Dillon, AJP. ${ }^{\mathrm{a}}$, Specht, $A .^{\mathrm{a}, \mathrm{b}}$ and Barros, $N M .^{\mathrm{a} *}$ \\ ${ }^{a}$ Instituto de Biotecnologia, Centro de Ciências Agrárias e Biológicas, Universidade de Caxias do Sul - UCS, \\ Rua Francisco Getúlio Vargas, 1130, CP 1352, CEP 95070-560, Caxias do Sul, RS, Brazil

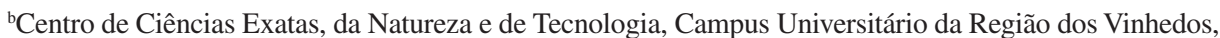 \\ Universidade de Caxias do Sul - UCS, Alameda João Dal Sasso, 800, CP 32, CEP 95700-000, Bento Gonçalves, RS, Brazil \\ *e-mail: nmbarros@ucs.br \\ Received January 28, 2009 - Accepted June 29, 2009 - Distributed November 30, 2010
}

(With 1 figure)

\begin{abstract}
Samples of the Bacillus thuringiensis (Bt) were collected from soil and insects. Eight isolates were selected from rural soil, 15 from urban soil and 11 from insects. These were evaluated for entomopathogenicity against larvae of Anticarsia gemmatalis and Culex quinquefasciatus. The pathogenicity tests showed that a higher percentage of isolates were active against $A$. gemmatalis (60\%) compared to C. quinquefasciatus $(31 \%)$. Probit analysis $\left(\mathrm{LC}_{50}\right)$ indicated that against A. gemmatalis four of the isolates presented values similar to the reference strain against $A$. gemmatalis, while against C. quinquefasciatus one isolate showed an $\mathrm{LC}_{50}$ similar to the reference strain (IPS-82). SDS-PAGE characterisation of two isolates showed a $27 \mathrm{kDa}$ protein fraction related to the $\mathrm{Bt}$ subspecies israelensis cytolytic toxin (cyt) gene. One $130 \mathrm{kDa}$ protein, possibly related to the Bt crystal inclusions (cry1) gene, was identified in the other two isolates, which were more toxic for lepidoptera; another isolate presented a protein of $100 \mathrm{kDa}$. Some new local Bt isolates had similar LC50 probit values to the reference strains.
\end{abstract}

Keywords: Anticarsia gemmatalis, Bacillus thuringiensis, Cry proteins, Culex quinquefasciatus, isolation.

\section{Isolados de Bacillus thuringiensis entomopatogênicos para Culex quinquefasciatus (Diptera: Culicidae) e Anticarsia gemmatalis (Lepidoptera: Noctuidae)}

\begin{abstract}
Resumo
Amostras de Bacillus thuringiensis (Bt) foram coletadas do solo e de insetos. Oito isolados foram coletados de solo rural, 15 de solo urbano e 11 de insetos, os quais foram avaliados quanto a sua entomopatogenicidade contra larvas de Anticarsia gemmatalis e Culex quinquefasciatus. Os testes de patogenicidade mostraram uma alta porcentagem de isolados ativos contra A. gemmatalis $(60 \%)$, comparado a C. quinquefasciatus $(31 \%)$. Por análise de probit $\left(\mathrm{CL}_{50}\right)$, verificou-se que quatro isolados apresentaram valores similares aos da estirpe de referência contra A. gemmatalis, enquanto somente um isolado mostrou CL50 similar à estirpe de referência (IPS 82) contra C.quinquefasciatus. A caracterização por SDS-PAGE de dois isolados mostrou uma proteína de $27 \mathrm{kDa}$ relativa à toxina citolítica (Cyt) de B. thuringiensis subespécie israelensis. Uma proteína de $130 \mathrm{kDa}$, possivelmente relacionada à família do gene cry 1 , foi identificada em outros dois isolados, os quais foram mais tóxicos para lepidópteros, enquanto que os outros dois isolados apresentaram uma proteína de $100 \mathrm{kDa}$. Alguns novos isolados locais de B. thuringiensis apresentaram valores de CL50 similares às estirpes de referência.
\end{abstract}

Palavras-chave: Anticarsia gemmatalis, Bacillus thuringiensis, proteínas Cry, Culex quinquefasciatus, isolamento.

\section{Introduction}

The bacterium Bacillus thuringiensis has been used to control insects belonging to a variety of different orders. However, further studies are needed to obtain and characterise isolates effective against specific insects, especially for the control of Diptera (Saadoun et al., 2001; Praça et al., 2004; Cavados et al., 2005; Ohgushi et al., 2005; Jara et al., 2006; Armengol et al., 2007), Lepidoptera (Dias et al., 1999; Asano et al., 2000; Uribe et al., 2003; Martínez et al., 
2005; Armengol et al., 2007), Hymenoptera (Pinto et al., 2003) and Coleoptera (Martins et al., 2007).

In southern Brazil, some of the most important insect pests belong to the Culicidae (Diptera: Nematocera), with haematophagous habits having medical importance (e.g. Consoli and Oliveira, 1994) while representatives of the Noctuidae (Lepidoptera), such as the velvet bean caterpillar (Anticarsia gemmatalis), the corn earworm (Helicoverpa zea), the armyworm (Spodoptera frugipeda), the cutworms (Agrotis ipslon) and the semilooper (Pseudoplusia includens) cause damage and economic loss to important crops (Gallo et al., 2002).

The search for new B. thuringiensis isolates and their characterisation has been carried out by several research groups in different countries (Dias et al., 1999; Uribe et al., 2003; Pinto et al., 2003; Cavados et al., 2005; Jara et al., 2006), these isolates being important in the control of insects because they represent new alternatives in integrated pest management (IPM). The majority of natural $B$. thuringiensis isolates with insecticidal activity are effective against lepidoptera larva (Alves et al., 1998), with $B$. thuringiensis strains active against diptera or coleoptera being more difficult to isolate (Mohammedi et al., 2006; Armengol et al., 2007).

Bioassays have been used to examine new $B$. thuringiensis isolates from soil, leaves and insects that induce mortality in dipterous and lepidopterous insects and are equal, or superior, to $B$. thuringiensis reference strain B.thuringiensis IPS-82 and kurstaki strain HD-1 (Bobrowski et al., 2001; Jara et al., 2006).

Strains of $B$. thuringiensis produce several proteinaceous $\delta$-endotoxins, known as crystal inclusion (Cry) proteins, classified according to the amino acid sequence determining their specificity (Crickmore et al., 1998). The Cry 2, Cry 4, Cry 10, Cry 11, Cry 16, Cry 17, Cry 19 toxins are generally described as active against dipterans while the Cry 1, Cry 9 and Cry 2 toxins are effective against lepidopterans. Moreover, B. thuringiensis subsp. israelensis also produces cytolytic toxins (Cyt) with recognised activity and specificity against dipterans (Crickmore et al., 1998; Armengol et al., 2007).

The purpose of the study reported in this paper was obtain and characterise novel $B$. thuringiensis isolates from soil and insect samples collected in the Serra Gaúcha, a hilly region in the southernmost Brazilian state of Rio Grande do Sul. Bioassays were conducted with isolates using Culex quinquefasciatus and A. gemmatalis Hübner and a protein profile study of the strains was carried out using Sodium dodecyl sulfate-polyacrylamide gel electrophoresis (SDS-PAGE) characterisation.

\section{Material and Methods}

\subsection{Isolation of B. thuringiensis}

The B. thuringiensis strains were isolated from soil and insect samples from the Serra Gaúcha, Rio Grande do Sul, Brazil. The soil samples were collected from unused urban land and native vegetation in rural areas. Isolation of soil samples followed the methodology recommended by WHO (1985) and the collection and storage procedures were according to Lezama-Gutiérrez et al. (2001). Unless otherwise stated, all chemicals were purchased from Sigma (USA) and culture media components from Oxoid (UK) or Merck (Germany).

The urban B. thuringiensis isolates were obtained from naturally infected specimens of the common housefly, Musca domestica (Diptera: Muscidae), collected from vacant urban land, while the rural $B$. thuringiensis isolates were obtained from the moths Anicla ignicans, growing on wheat (Triticum aestivum) and Agrotis malefida (Lepidoptera: Noctuidae), growing on cabbage (Brassica oleracea). The isolation of B. thuringiensis from insects followed the methodology described by Alves et al. (1998). Briefly, the dead insects were dispatched and then macerated in saline solution $(0.5 \%(\mathrm{w} / \mathrm{v}) \mathrm{NaCl})$ using a sterilised mortar and pestle, after which $1 \mathrm{ml}$ aliquots were transferred to sterilised test-tubes, thermally shocked at $80^{\circ} \mathrm{C}$, appropriately diluted in saline and $100 \mu \mathrm{l}$ portions inoculated into of Luria Bertani (LB) solid medium (containing $\left(\mathrm{g} \mathrm{l}^{-1}\right)$ : agar, 15; tryptone, 10; yeast extract, $5 ; \mathrm{NaCl}, 5 . \mathrm{pH} 7.5$ ) which was then incubated for $24 \mathrm{~h}$ at $28^{\circ} \mathrm{C}$ and the Bacillus colonies selected using the same methodology as that used for the soil samples. The isolates were coded as follows: $\mathrm{SR}=$ rural soil; $\mathrm{SU}=$ urban soil; ID-MD = M. domestica $; \mathrm{IL}-\mathrm{ANI}=$ Anicla ignicans; and IL-AGR = Agrotis malefida .

To select for endospore-forming bacteria in the soilsamples and the insect preparations described above, we suspended one gramme of soil in $10 \mathrm{ml}$ of $0.87 \%(\mathrm{v} / \mathrm{v})$ $\mathrm{NaCl}$ contained in sterile tubes and heated appropriate dilutions of the suspension at $80^{\circ} \mathrm{C}$ for $12 \mathrm{~min}$ in a water bath, after which $100 \mu \mathrm{l}$ aliquots were plated onto nutrient agar (containing: $\mathrm{g} \mathrm{L}^{-1}$; peptone, 5; yeast extract, 2; $\mathrm{NaCl}, 5$; agar, 15. $\mathrm{pH} 7.4$ ) and incubated at $28^{\circ} \mathrm{C}$ for $24 \mathrm{~h}$. After incubation, we used the World Health Organization (WHO) colony morphology criteria (WHO, 1985) to select circular, scalloped-edged, non-pigmented presumptive $B$. thuringiensis colonies. The colonies were individually subcultured into LB broth supplemented with $10 \mathrm{~g} \mathrm{~L}^{-1}$ penicillin and incubated for $24 \mathrm{~h}$ at $28{ }^{\circ} \mathrm{C}$ to verify in phase contrast microscopy those exhibiting protein crystals considered to be B. thuringiensis (Silva-Werneck and Monnerat, 2001).

The $B$. thuringiensis isolates were conserved at $-18^{\circ} \mathrm{C}$ in Eppendorf tubes containing NYSM medium (Difco nutrient agar supplemented with: $0.05 \%(\mathrm{w} / \mathrm{v})$ yeast extract, $5 \times 10^{-5} \mathrm{M} \mathrm{MnCl}_{2}, 7 \times 10^{-4} \mathrm{M} \mathrm{CaCl}_{2}$ and $10-3 \mathrm{M} \mathrm{MgC1}_{2}$ ) and kept in the bacteria culture collection of the Pest Control Laboratory, Biotechnology Institute, Universidade de Caxias do Sul, Caxias do Sul, Brazil.

\subsection{Bioassays}

Bioassays were carried out on the isolates shown in Table 1 using the mosquitoes $C$. quinquefasciatus and the moth A. gemmatalis, which were reared in our laboratory under controlled conditions $\left(25^{\circ} \mathrm{C} \pm 1{ }^{\circ} \mathrm{C}, 65 \%+10 \%\right.$ 
relative humidity, 12 hours photophase) according to the procedures of Consoli and Oliveira (1994) for the former and Hoffmann-Campo et al. (1985) for the latter.

Mean percentage mortality was determined using a selective bioassay to identify isolates capable of killing at least $30 \%$ of the larvae tested at a specific concentration of the isolate. Virulence was assessed based on the dosedependent toxicity of each isolate. Triplicate bioassays were used in all cases. For $C$. quinquefasciatus mosquitoes the entomopathogenicity of each isolate was assessed by adding $200 \mu \mathrm{l}$ of spore suspension, containing $3 \times 10^{8} \mathrm{~mL}^{-1}$ spores, to $300 \mathrm{ml}$ plastic cups containing $100 \mathrm{~mL}$ of de-chlorinated water supplemented with $0.001 \mathrm{~g} \mathrm{~L}^{-1}$ of brewers yeast and 25 third-instar $C$. quinquefasciatus larvae. Negative controls received $200 \mu \mathrm{L}$ of de-chlorinated water instead of spore suspension and the positive controls received 200 $\mu \mathrm{L}$ of $B$. thuringiensis reference strain IPS-82, known to be highly entomopathogenic to dipterans (Fillinger et al., 2003), at the same spore concentration. Mortality was evaluated after 48 hours. For A. gemmatalis moths the entomopathogenicity of each isolate was assessed by applying $100 \mu \mathrm{l}$ of spore suspension, containing $3 \times 10^{8}$ spores, to a disk (diameter $=25 \mathrm{~mm}$ ) cut from fresh leaves of the common bean (Phaseolus vulgaris L.) contained in a Petri dish along with 10 third-instar A. gemmatalis larvae. The larvae remained in contact with the suspension for 24 hours, after which they were individually placed into $50 \mathrm{~mL}$ plastic cups containing a pathogen-free artificial diet (Parra, 2001). Negative controls received $200 \mu \mathrm{L}$ of de-chlorinated water instead of spore suspension and the positive controls received $200 \mu \mathrm{L}$ of $B$. thuringiensis kurstaki strain HD1, known to be highly entomopathogenic to lepidopterans (Lee et al., 2001), at the same spore concentration. The A. gemmatalis bioassays were evaluated on the $2^{\text {nd }}$ and $7^{\text {th }}$ day.

Virulence assessment was carried out on the isolates in Table 1, which presented the best growth and sporulation and were pathogenic for at least one species. Using the methods described above and appropriate controls we tested five isolates from rural soil, six from urban soil and five from insects (Table 2) at the following spore concentrations (spores $\mathrm{mL}^{-1}$ ) were assessed: $1.5 \times 10^{3}, 1.5 \times 10^{4}, 1.5 \times$ $10^{5}, 1.5 \times 10^{6}$ and $1.5 \times 10^{7}$. The $50 \%$ lethal concentration $\left(\mathrm{LC}_{50}\right)$ was calculated for each isolate using probit analysis (Finney, 1971). The mean fifty-percent lethal concentration $\left(\mathrm{LC}_{50}\right)$ values are given as probit values and their $95 \%$ confidence limits (CI) for a spore concentration of $1.5 \times$ $10^{7} \mathrm{~mL}^{-1}$ and $\mathrm{n}=3$. The toxicity of the isolates for each insect were compared using analysis of variance (ANOVA) and the SPSS Program (Kuo et al., 1992)

\subsection{SDS-PAGE analysis}

The protein profiles of the isolates that showing the best toxicity were analysed using SDS-PAGE in $12 \%$ $(\mathrm{w} / \mathrm{v})$ acrylamide gel. The proteins were extracted from the culture according to Lecadet et al. (1991) and $15 \mu \mathrm{L}$ of each sample were loaded onto the gel. After electrophoresis, the gel was stained and fixed according to the method described by Laemmli (1970). The reference isolate was B. thuringiensis IPS 82 .

\section{Results}

\subsection{Isolation and evaluation of pathogenicity}

A total of 721 bacterial colonies were isolated, 555 (77\%) from urban and rural soil samples and $166(23 \%)$ from insects. Of the colonies isolated, 172 (31\% of 555) of the soil isolates and 59 (36\% of 166) of the isolates from insects were identified as B. thuringiensis, corresponding to a total of 231 isolates. We selected 35 isolates in NYSM medium, which presented higher growth (colony diameter) and presence of spores four days after inoculation ( 8 from rural soil, 15 from urban soil and 4 each from each species of insect) and evaluated them for entomopathogenicity against C. quinquefasciatus and A. gemmatalis (Table 1).

The mean percentage mortality test (Table 1 ) showed that a higher percentage of isolates were active against $A$. gemmatalis $(60 \%)$ than $C$. quinquefasciatus $(31 \%)$. Four isolates (SR-CR2, SR-CP2, SR-CR3 and SR-AP13) from rural soil were significantly $(\mathrm{p}=0.05)$ more toxic to $A$. gemmatalis than to $C$. quinquefasciatus. Isolate SR-AP5 produced $100 \%$ mortality against both $C$. quinquefasciatus and A. gemmatalis, while isolate SR-VV2 produced $100 \%$ mortality against $C$. quinquefasciatus only and isolate SR-CR2 showed the same mortality against $A$. gemmatalis (Table 1 ). The isolates from urban soil followed a similar pattern, except that none showed $100 \%$ mortality (Table 1 ).

Only four $(21 \%)$ of the 12 isolates from insects produced more than $30 \%$ mortality against $C$. quinquefasciatus, with the muscid isolates ID-MD4 and ID-MD1 both showing significantly $(\mathrm{p}=0.05)$ higher toxicity against mosquito larvae than moth larvae. Only 11 isolates obtained from insects were tested against $A$. gemmatalis. However, all of the 11 isolates tested showed mortality values higher than $30 \%$ when tested against $A$. gemmatalis larvae, with isolate IL-ANI4, obtained from a lepidopteran, causing $100 \%$ mortality. The isolates obtained from $M$. domestica produced in excess of $30 \%$ mortality both $C$. quinquefasciatus and $A$. gemmatalis larvae but were more effective against C. quinquefasciatus, with the isolates from the noctuids A. ignicans and A. malefida being more effective against A. gemmatalis (Table 1)

Isolate ID-MD4, obtained from the dipteran M. domestica, caused $100 \%$ mortality in C. quinquefasciatus, equal to that of reference strain IPS-82. However, the isolates obtained from lepidoptera were not highly pathogenic to diptera larvae but isolates IL-ANI4, IL-AGR3 and IL-AGR1 caused high mortality (77-100\%) against $A$. gemmatalis larvae and were similar in potency to reference strain HD1 (Table 1).

The results of the virulence assessment are presented as probit values in Table 2 where for each source category the isolates are ordered by probit value in decreasing A. gemmatalis entomopathogenicity. Against A. gemmatalis some isolates (IL-ANI4, LC $_{50}=3.49 ;$ SR-AP5, LC $_{50}=3.78$; 
Table 1. Mean percentage mortality \pm standard error $(\mathrm{SE})$ for larvae of the moth Anticarsia gemmatalis and the mosquito Culex quinquefasciatus exposed to Bacillus thuringiensis isolates obtained from different sources. The positive controls were the reference strains $B$. thuringiensis kurstaki HD-1 and $B$. thuringiensis israelensis IPS-82, effective against lepidopterans and dipterans respectively, which both gave $100 \%$ mortality. For each source category, the isolates are ordered by decreasing $A$. gemmatalis toxicity.

\begin{tabular}{|c|c|c|}
\hline \multirow{2}{*}{$\begin{array}{c}\text { Source } \\
\text { categories } \\
\text { and isolate code }\end{array}$} & \multicolumn{2}{|c|}{ Mean percentage mortality $\pm \mathrm{SE}$} \\
\hline & $\begin{array}{c}\text { A. } \\
\text { gemmatalis }\end{array}$ & $\begin{array}{c}C . \\
\text { quinquefasciatus }\end{array}$ \\
\hline \multicolumn{3}{|l|}{ Rural soil } \\
\hline SR-AP5 & $100.00 \pm 0.00$ & $100.00 \pm 0.00^{\mathrm{ns}}$ \\
\hline SR-CR2 & $100.00 \pm 0.00$ & $22.67 \pm 9.33^{*}$ \\
\hline SR-VV2 & $66.33 \pm 19.34$ & $100.00 \pm 0.00^{\mathrm{ns}}$ \\
\hline SR-CP2 & $60.00 \pm 10.41$ & $6.67 \pm 1.76^{*}$ \\
\hline SR-CR3 & $60.00 \pm 0.00$ & $2.67 \pm 1.33^{*}$ \\
\hline SR-VV1 & $55.33 \pm 29.36$ & $41.33 \pm 4.81^{\mathrm{ns}}$ \\
\hline SR-CB2 & $55 \pm 11.00$ & $69 \pm 31.00^{\mathrm{ns}}$ \\
\hline SR-AP13 & $22.00 \pm 4.16$ & $4.00 \pm 2.31^{*}$ \\
\hline \multicolumn{3}{|l|}{ Urban soil } \\
\hline SU-SM1 & $88.67 \pm 11.33$ & $72.00 \pm 6.11^{\mathrm{ns}}$ \\
\hline SU-GBA2 & $88.67 \pm 11.33$ & $44.00 \pm 6.00^{*}$ \\
\hline SU-ALF6 & $88.67 \pm 9.33$ & $25.33 \pm 9.84^{*}$ \\
\hline SU-SM2 & $77.33 \pm 8.51$ & $16.00 \pm 6.11^{\mathrm{ns}}$ \\
\hline SU-BF7 & $77,33 \pm 11.33$ & $57.33 \pm 3.53^{\mathrm{ns}}$ \\
\hline SU-GBA8 & $66.67 \pm 3.33$ & $21.33 \pm 5.8^{*}$ \\
\hline SU-GBA1 & $56.00 \pm 11.00$ & $60.00 \pm 10.07^{\mathrm{ns}}$ \\
\hline SU-BF4 & $55.00 \pm 11.00$ & $68.00 \pm 4.00^{\mathrm{ns}}$ \\
\hline SU-GBA4 & $53.33 \pm 24.04$ & $8.00 \pm 4.62^{\mathrm{ns}}$ \\
\hline SU-FAR3 & $44.00 \pm 11.00$ & $29.33 \pm 4.81^{\mathrm{ns}}$ \\
\hline SU-GAL1 & $40.00 \pm 11.55$ & $12.67 \pm 8.67^{\mathrm{ns}}$ \\
\hline SU-GBA6 & $40.00 \pm 20.00$ & $5.33 \pm 2.19^{\mathrm{ns}}$ \\
\hline SU-FAR4 & $20.00 \pm 6.11$ & $6.67 \pm 6.67^{*}$ \\
\hline SU-GB1 & $26.67 \pm 6.67$ & $9.67 \pm 3.18^{*}$ \\
\hline SU-SM12 & $26.67 \pm 6.67$ & $5.33 \pm 2.03^{\mathrm{ns}}$ \\
\hline \multicolumn{3}{|l|}{ Insects } \\
\hline \multicolumn{3}{|l|}{ M. domestica } \\
\hline ID-MD4 & $66.33 \pm 5.17$ & $100.00 \pm 0.00^{*}$ \\
\hline ID-MD1 & $55.00 \pm 3.00$ & $98.67 \pm 0.85^{*}$ \\
\hline ID-MD5 & $33.00 \pm 1.80$ & $40.00 \pm 2.31^{\mathrm{ns}}$ \\
\hline ID-MD3 & NT & $92.67 \pm 2.37$ \\
\hline \multicolumn{3}{|l|}{ A. ignicans } \\
\hline IL-ANI4 & $100.00 \pm 0.00$ & $18.67 \pm 2.73^{*}$ \\
\hline IL-ANI2 & $53.33 \pm 3.88$ & $5.33 \pm 1.14^{*}$ \\
\hline IL-ANI3 & $40.00 \pm 5.03$ & $10.67 \pm 2.20^{*}$ \\
\hline IL-ANIH & $33.00 \pm 6.26$ & $6.67 \pm 1.01^{\mathrm{ns}}$ \\
\hline \multicolumn{3}{|l|}{ A. malefida } \\
\hline IL-AGR3 & $88.67 \pm 3.85$ & $0.67 \pm 0.09^{*}$ \\
\hline IL-AGR1 & $77.33 \pm 4.37$ & $0.67 \pm 0.19^{*}$ \\
\hline IL-AGR2 & $55.00 \pm 2.52$ & $0.67 \pm 0.04^{*}$ \\
\hline IL-AGR5 & $33.67 \pm 7.97$ & $5.33 \pm 0.24^{\mathrm{ns}}$ \\
\hline
\end{tabular}

*Significant difference between the A. gemmatalis and $C$. quinquefasciatus columns by the Student's t-test assuming different variances $(\mathrm{n}=3, \mathrm{p}=0.05)$. $\mathrm{NT}=$ Not tested, $\mathrm{ns}=$ non-significant.
SU-SM2, $\mathrm{LC}_{50}=4.69$; and SR-CR2, $\mathrm{LC}_{50}=4.77$ ) were as virulent as reference strain HD1 $\left(\mathrm{LC}_{50}=3.47\right)$, while against $C$. quinquefasciatus isolate $\mathrm{SU}-\mathrm{BF} 4\left(\mathrm{LC}_{50}=4.67\right)$ did not differ in virulence when compared with reference strain IPS-82 $\left(\mathrm{LC}_{50}=5.13\right)$ (Table 2).

The protein profiles of isolates SR-AP5 and SR-CR2, obtained from rural soil, showed high molecular weight proteins of $130 \mathrm{kDa}$. Isolates ID-MD1 and ID-MD4, from M. domestica, also showed a $130 \mathrm{kDa}$ protein band and this displaced similar electrophoretic patterns regarding the number and position of protein bands to those of the strain IPS-82 (Figure 1). Isolate SU-SM1, from urban soil, and isolates IL-ANI4 and IL-AGR3, from lepidoptera (Figure 1a) along with isolates SU-SM2 and IL-ANIH and (Figure 1b) showed higher virulence against $A$. gemmatalis and presented bands with a molecular weight of $25 \mathrm{kDa}$ and $120 \mathrm{kDa}$. The rural soil isolate SR-VV2, the most virulent against mosquito larvae, presented a large protein band of approximately $100 \mathrm{kDa}$.

\section{Discussion}

Some of our new B. thuringiensis isolates from both soil and insects produced high mean percentage mortality in C. quinquefasciatus, A. gemmatalis or both, confirming the reports of various authors that both soil and insects are good sources for new entomopathogenic $B$. thuringiensis strains (Hansen et al., 1997; Schnepf et al., 1998; Kim, 2000; Cavados et al., 2001; Pinto et al., 2003; Quesada-Moraga et al., 2004; Hajaij et al., 2005; Hernandez et al., 2005).

The percentage of $B$. thuringiensis isolates obtained in our study (31\% from soil and $36 \%$ from insects) was similar to that reported by Chilcot and Wigley (1993) but lower than the $82 \%$ obtained by Uribe et al. (2003) and the $90 \%$ reported by Bravo et al. (1998). The $36 \%$ of $B$. thuringiensis recovered from insects was similar to the $40 \%$ reported by Pinto et al. (2003), but less than the $60 \%$ obtained by Hernandez et al. (2005).

The pathogenicity tests (Table 1 ) showed a higher percentage of strains active against $A$. gemmatalis (60\%) than $C$. quinquefasciatus (31\%). In general, the isolates obtained from insects showed higher activity than those recovered from soil, and it was found that isolates obtained from dipterous and lepidopterous larvae were more effective against $C$. quinquefasciatus and A. gemmatalis larvae, respectively. Isolate ID-MD4, obtained from $M$. domestica, showed the same percentage mortality against $C$. quinquefasciatus as the reference strain IPS-82. Similar observations were reported by Cavados et al. (2005), who reported that bioassays of a B. thuringiensis isolate obtained from the black fly Simulium pertinax, which had been captured in a field in southeastern Brazil, was not only effective against $S$. pertinax but also had comparable toxicity against the important disease vector Aedes aegypti as reference strain IPS- 82 which is only effective against mosquitoes.

The isolates obtained from lepidoptera showed higher activity for $A$. gemmatalis, with isolates IL-ANI3, IL- 
Table 2. Mean virulence of Bacillus thuringiensis (Bt) isolates against the moth Anticarsia gemmatalis and the mosquito Culex quinquefasciatus. The mean fifty-percent lethal concentration $\left(\mathrm{LC}_{50}\right)$ probits and their $95 \%$ confidence limits $(\mathrm{CI})$ are shown for a spore concentration of $1.5 \times 10^{7} \mathrm{~mL}^{-1}$ and $\mathrm{n}=3$. For each source category, the isolates are ordered by decreasing A. gemmatalis toxicity. The positive controls are the reference strains B. thuringiensis subsp. kurstaki strain HD1 and $B$. thuringiensis IPS-82, effective against lepidopterans and dipterans respectively.

\begin{tabular}{|c|c|c|c|c|}
\hline \multirow{3}{*}{$\begin{array}{l}\text { Source categories } \\
\text { and } B t \text { isolate code }\end{array}$} & \multicolumn{4}{|c|}{ Probit values for larvae } \\
\hline & \multicolumn{2}{|c|}{ A. gemmatalis } & \multicolumn{2}{|c|}{ C. quinquefasciatus } \\
\hline & Mean $^{\dagger}$ & $95 \% \mathrm{CI}$ & Mean $^{\dagger}$ & $95 \% \mathrm{CI}$ \\
\hline \multicolumn{5}{|l|}{ Rural soil } \\
\hline SR-AP5 & $3.78^{\mathrm{b}}$ & 2.45 to 4.96 & $7.76^{\mathrm{a}}$ & 6.86 to 12.64 \\
\hline SR-CR2 & $4.77^{\mathrm{b}}$ & 1.14 to 5.76 & $7.22^{\mathrm{b}}$ & 5.96 to 10.36 \\
\hline SR-VV2 & $7.66^{\mathrm{a}}$ & 6.93 to 10.41 & $5.20^{\mathrm{bc}}$ & 3.11 to 6.11 \\
\hline SR-CB2 & $7.98^{\mathrm{a}}$ & 7.29 to 10.09 & $5.74^{\mathrm{bc}}$ & 5.28 to 6.10 \\
\hline SR-VV1 & $8.09^{\mathrm{a}}$ & 7.32 to 10.93 & - & - \\
\hline \multicolumn{5}{|l|}{ Urban soil } \\
\hline SU-SM2 & $4.69^{b}$ & 5.08 to 5.74 & - & - \\
\hline SU-SM1 & $5.80^{\mathrm{ab}}$ & 3.12 to 6.67 & $6.15^{b}$ & 5.67 to 6.56 \\
\hline SU-GBA1 & $6.39^{\mathrm{ab}}$ & 5.57 to 7.15 & $6.40^{\mathrm{b}}$ & 6.01 to 6.78 \\
\hline SU-ALF6 & $7.59^{\mathrm{a}}$ & 6.59 to 18.51 & $6.00^{\mathrm{bc}}$ & 5.25 to 6.53 \\
\hline SU-BF4 & $7.66^{\mathrm{a}}$ & 6.90 to 10.25 & $4.67^{c}$ & 2.39 to 5.42 \\
\hline SU-FAR3 & $7.88^{\mathrm{a}}$ & 6.94 to 14.55 & - & - \\
\hline \multicolumn{5}{|l|}{ Insects } \\
\hline \multicolumn{5}{|l|}{ M. domestica } \\
\hline ID-MD1 & $6.13^{\mathrm{ab}}$ & 3.82 to 7.20 & $6.74^{\mathrm{ab}}$ & 5.41 to 9.34 \\
\hline ID-MD4 & $6.24^{\mathrm{ab}}$ & 3.72 to 7.55 & $7.82^{\mathrm{ab}}$ & 6.64 to 12.41 \\
\hline \multicolumn{5}{|l|}{ A. ignicans } \\
\hline IL-ANI4 & $3.49^{\mathrm{b}}$ & 2.64 to 4.91 & $8.05^{\mathrm{a}}$ & 7.32 to 10.23 \\
\hline IL-ANIH & $7.37^{\mathrm{a}}$ & 6.95 to 7.97 & - & - \\
\hline \multicolumn{5}{|l|}{ A. malefida } \\
\hline IL-AGR3 & $7.34^{\mathrm{a}}$ & 6.68 to 8.79 & - & - \\
\hline \multicolumn{5}{|l|}{ Positive controls } \\
\hline Btk - HD1 & $3.47^{\mathrm{b}}$ & 1.87 to 4.89 & NT & NT \\
\hline IPS-82 & NT & NT & $5.13^{c}$ & 4.81 to 5.36 \\
\hline
\end{tabular}

$\dagger$ Within the same column, different superscript letters indicate a significant difference between means by the Duncan's test $(\mathrm{n}=3, \mathrm{p}=0.05)$. A hyphen $(-)$ indicates no activity and $\mathrm{NT}=$ not tested.

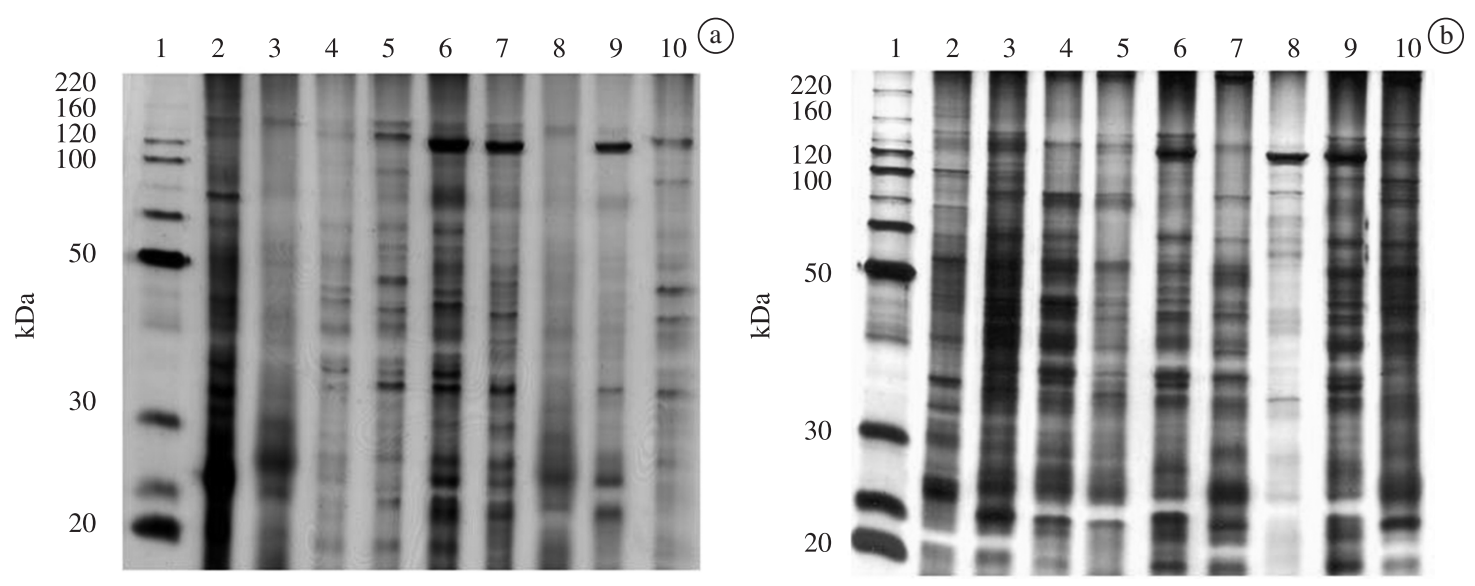

Figure 1. SDS-PAGE of the spore-crystal mixture (52-hour culture) of the isolates of Bacillus thuringiensis. a: 1 - molecular weight marker (Invitrogen); 2 - IPS-82; 3 - ID-MD1; 4 - SU-BF4; 5 - SR-AP5; 6 - IL-ANI4; 7 - SU-SM1; 8 - ID-MD4; 9 - IL-AGR3; 10 - SR-CR2; b: 1 - molecular weight marker (Invitrogen); 2 - IPS-82; 3 - SU-GBA1; 4 - SU-ALF6; 5 - SUFAR3; 6 - IL-ANIH; 7 - SR-VV1; 8 - SR-VV2; 9 - SU-SM2; 10 - SR-CB2. 
ANI4, IL-AGR1 IL-AGR2 and IL-AGR3 producing higher A. gemmatalis mortality and virulence compared to the isolates recovered from soil and $M$. domestica. Similar results were obtained with $B$. thuringiensis isolates obtained from insects by Aronson (1993). Regarding the isolates recovered from A. ignicans, it should be pointed out that Monnerat et al. (2002) and Porcar and Caballero (2000) obtained isolates from lepidoptera with high toxic activity against $S$. frugiperda, $H$. armigera and $S$. littoralis. Several authors have also reported that soil can be a source of entomopathogenic B. thuringiensis isolates with toxicity against lepidoptera (Silva et al., 2004; Praça et al., 2004; Bobrowski et al., 2001).

Our finding that only isolate SU-BF4 presented a $\mathrm{CL}_{50}$ similar to reference strain IPS-82 (Table 2) supports other studies which have found that most new $B$. thuringiensis isolates obtained from soil were less effective against dipteran insects (Praça et al., 2004; Martínez et al., 2005).

Martin and Travers (1989) also reported that $B$. thuringiensis isolates obtained from soil were more active against lepidoptera than mosquitoes, with more than double the number of isolates being entomopathogenic for lepidoptera than for diptera. Other authors have reported that of a large number of isolates, which were effective against lepidoptera, few or none were active against diptera (Dias et al., 1999; Kim, 2000; Martínez and Caballero, 2002). Our observations support the view that $B$. thuringiensis isolates from soil usually exhibit specificity to their hosts (Hansen et al., 1997; Mohammedi et al., 2006).

In our study, however, the isolates, which were virulent for $C$. quinquefasciatus were also virulent for A. gemmatalis, similar results having been reported by Silva et al. (2004) and Martínez et al. (2005). This suggests that soil samples containing $B$. thuringiensis isolates entomopathogenic for a specific insect species are rare compared to soil samples containing $B$. thuringiensis isolates with broad-spectrum activity.

The SDS-PAGE technique detected high molecular weight proteins in some isolates, with isolate SR-AP5 showing a $65 \mathrm{kDa}$ band and SR-CR2 showing a $130 \mathrm{kDa}$ band (Figure 1). The high lepidopteran toxicity of these strains may have been due to the presence of these proteins, which may have been related to the cry 1 gene described by several workers (Li et al., 2002; Monnerat et al., 2002; Uribe et al., 2003). The protein profile showing $65 \mathrm{kDa}$ and $130 \mathrm{kDa}$ bands is similar to pattern obtained from reference strain HD1 (Dias et al., 1999; Li et al., 2002; Medeiros et al., 2005). The relationship between the protein profile of isolates ID-MD1 and ID-MD4 and their toxicity to $C$. quinquefasciatus may have been due to the $27 \mathrm{kDa}$ band in the protein profile of these isolates (Figure 1), since the Cyt protein, known to trigger cytolytic action against diptera, also resolves at $27 \mathrm{kDa}$ (Crickmore et al., 1998; Tokcaer et al., 2006). Isolate SR-VV2 more virulent for $C$. quinquefasciatus than A. gemmatalis, displayed a band at approximately $100 \mathrm{kDa}$ (Figure 1b), similar results have been reported for two isolates toxic against A. aegypti (Cavados et al., 2001). The isolates showing
$25 \mathrm{kDa}$ and $120 \mathrm{kDa}$ bands (Figures I and II) were more virulent for A. gemmatalis, similar results having been reported for other soil isolates from Rio Grande do Sul (Pinto and Fiuza, 2003).

During the study reported in this paper, we obtained novel $B$. thuringiensis isolates, which showed similar virulence against $C$. quinquefasciatus and A. gemmatalis as the reference strains $B$. thuringiensis IPS-82 and HD1. A further interesting aspect of our research was the recovery of some B. thuringiensis isolates, such as SR-AP5 and SR$\mathrm{VV} 2$, which were virulent to both of the test organisms, and which may have an important role in future biological control programs.

Acknowledgements - This work was supported by grants and fellowships from UCS, CAPES, CNPq and FAPERGS.

\section{References}

ALVES, SB., MOINO, JR. and ALMEIDA, JEM., 1998. Desenvolvimento, potencial de uso e comercialização de produtos microbianos. In ALVES, SB. (Ed.). Controle microbiano de insetos. São Paulo: FEALQ. p. 1143-1163.

ARMENGOL, G., ESCOBAR, MC., MALDONADO, ME. and ORDUZ, S., 2007. Diversity of Colombian strains of Bacillus thuringiensis with insecticidal activity against dipteran and lepidopteran insects. Journal of Applied Microbiology, vol. 102, no. 1, p. $77-88$.

ARONSON, AI., 1993. The two faces of Bacillus thuringiensis: insecticidal proteins and post-exponencial survival. Molecular Microbiology, vol. 7, no. 4, p. 489-496.

ASANO, S., OGIWARA, K., INDRASITH, LS., TAKAHASHI, M., SUZUKI, N. and HORI, H., 2000. Synergism of the spore on insecticidal activity of $\delta$-endotoxin of Bacillus thuringiensis against diamondback moth, Plutella xylostella (Lepidoptera: Yponomeutidae) is not observed at late stage in bioassay. Applied Entomology and Zoology, vol. 35, no. 4, p. 583-590.

BOBROWSKI, VL., PASQUALI, G., BODANESE-ZANETTINI, MH. and FIUZA, LM., 2001. Detection of cry1 genes in Bacillus thuringiensis isolates from south of Brazil and activity against Anticarsia gemmatalis (Lepidoptera:Noctuidae). Brazilian Journal of Microbiology, vol. 32, no. 2, p. 105-109.

BRAVO, A., SARABIA, S., LOPEZ, L., ONTIVEROS, H., ABARCA, C., ORTIZ, A., ORTIZ, M., LINA, L., VILLALOBOS, FJ., PEÑA, G., NUÑEZ-VALDEZ, M-E., SOBERÓN, M. and QUINTERO, R., 1998. Characterization of cry genes in a Mexican Bacillus thuringiensis strain collection. Applied and Environmental Microbiology, vol. 64, no. 12, p. 4965-4972.

CAVADOS, CFG., FONSECA, R., CHAVES, JQ., ARAÚJOCOUTINHO, CJPC. and RABINOVITCH, L., 2005. A new black fly isolate of $B$. thuringiensis autoagglutinating strain highly toxic to Simulium pertinax (Kollar) (Diptera, Simuliidae) larvae. Memórias do Instituto Oswaldo Cruz, vol. 100, no. 7, p. 795-797.

CAVADOS, CFG., FONSECA, RN., CHAVES, JQ., RABINOVITCH, L. and ARAÚJO-COUTINHO, CJPC., 2001. Identification of entomopathogenic Bacillus isolated from Simulium (Diptera: Simuliidae) larvae and adults. Memórias do Instituto Oswaldo Cruz, vol. 96, no. 7, p. 1017-1021. 
CHILCOT, CN. and WIGLEY, PJ. 1993. Isolation and toxicity of $B$. thuringiensis from soil and insect habitats in New-Zealand. Journal of Invertebrate Pathology, vol. 61, no. 3, p. 244-247.

CONSOLI, RAGB. and OLIVEIRA, RL., 1994. Principais mosquitos de importância sanitária no Brasil. Rio de Janeiro: Fiocruz. 225 p.

CRICKMORE, N., ZEIGLER, DR., SCHNEPF, E., RIE, J. van, LERECLUS, D., BAUM, J., BRAVO, A. and DEAN, DH., 1998. Bacillus thuringiensis toxin nomenclature. Microbiology and Molecular Biology Reviews, vol. 62, no. 3, p. 807-813.

DIAS, SC., SAGARDOY, MA., SILVA, SF. and DIAS, JMCS., 1999. Characterization and phatogenic evaluation of $B t$ and $B$. sphaericus isolates from Argentinean soils. BioControl, vol. 44, no. 1, p. 59-71.

FILLINGER, U., BART, GJ., KNOLS, BG. and BECKER, N., 2003. Efficacy and efficiency of Bacillus thuringiensis var. israelensis $\mathrm{e}$ Bacillus sphaericus formulations against Afrotropical anophelines in Western Kenya. Tropical Medicine and International Health, vol. 8, no. 1, p. 37-47.

FINNEY, D., 1971. Probit Analysis. Cambridge: Cambridge University Press. 80 p.

GALLO, D., NAKANO, O., SILVEIRA NETO, S., CARVALHO, RPL., BAPTISTA, GC., BERTI FILHO, E., PARRA, JRP., ZUCCHI, RA., ALVES, SB., VENDRAMIM, JD., MARCHINI, LC., LOPES, JRS. and OMOTO, C. 2002. Entomologia Agrícola. Piracicaba: Livroceres. 920 p.

HAJAIJ, M., CARRON, A., DELEUZE, J., GAVEN, B., SETIERRIO, M-L., VIGO, G., THIÉRY, I., NIELSEN-LEROUX, CN. and LAGNEAU, C., 2005. Low Persistence os Bacillus thuringiensis serovar israelensis Spores in four Mosquito Biotopes of a Salt Marsh in Southern France. Microbial Ecology, vol. 50, no. 4, p. $475-487$

HANSEN, BM., DAMGAARD, PH., EILENBERG, J. and PEDERSEN, JC., 1997. Molecular and phenotypic characterization of B. thuringiensis isolated from leaves and insects. Journal of Invertebrate Pathology, vol. 71, no. 2, p. 106-114.

HERNANDEZ, CS., ANDREW, R., BEL, Y. and FERRÉ, J., 2005. Isolation and toxicity of Bacillus thuringiensis from potato growing areas in Bolivia. Journal of Invertebrate Pathology, vol. 88 , no. 1 , p. 8-16.

HOFFMAN-CAMPO, CB., OLIVEIRA, EB. and MOSCARDI, F., 1985. Criação massal da lagarta-da-soja (Anticarsia gemmatalis). Londrina: Embrapa-CNPSo. 14 p. EmbrapaCNPSo. Documentos, 10.

JARA, S., MADUELI, P. and ORDUZ, S., 2006. Diversity of Bacillus thuringiensis strains in the maize and bean phylloplane and their respective soils in Colombia. Journal of Applied Microbiology, vol. 101, no. 1, p. 117-124.

KIM, HS., 2000. Comparative study of the frequency, flagellar serotype, crystal shape, toxicity, and Cry genes contents of $B$, thuringiensis from three environments. Current Microbiology, vol. 41 , no. 3, p. 250-256.

KUO, J., FOX, E. and MacDONALD., 1992. Sigmastat: statistical software for working scientists. User manual. San Francisco, CA: Jandel Scientific.

LAEMMLI, UK. 1970. Cleavage of structural proteins during the assembly of the head of bacteriophage T4. Nature, vol. 227, no. 5259 , p. $680-685$.
LECADET, MM., CHAUFAUX, J., RIBIER, J., LERECLUS, D., 1991. Construction of novel Bacillus thuringiensis strains with different insecticidal activities by transduction and transformation. Applied and Environmental Microbiology, vol. 58, no. 3, p. 840-849.

LEE, IH., JE, YH., CHANG, JH., ROH, JY., OH, HW., LEE, SG., SHIN, SC. and BOO, KS. 2001. Isolation and characterization of Bacillus thuringiensis ssp. kurstaki strain toxic to Spodoptera exigua and Culex pipiens. Current Microbiology, vol. 43, no. 4, p. $284-287$.

LEZAMA-GUTIÉRREZ, R., HAMM, J., MOLINA-OCHOA, J., LÓPEZ-EDUARDS, M., PESCADOR-RUBIO, A., GONZALEZ-RAMIREZ, M. and STYER, EL., 2001. Occurrence of entomopathogens of Spodoptera frugiperda in the Mexican States of Michoacán, Colima, Jalisco and Tamaulipas. Florida Entomologist, vol. 84, no. 1, p. 23-30.

LI, MS., JE, YH., LEE, IH., CHANG, JH., ROH, JY., KIM, HS., $\mathrm{OH}, \mathrm{HW}$. and BOO, KS., 2002. Isolation and characterization of a strain of Bacillus thuringiensis ssp. kurstaki containing a new ä-endotoxin gene. Current Microbiology, vol. 45, no. 4, p. 299-302.

MARTIN, PAW. and TRAVERS, RS., 1989. Worldwide abundance and distribution of Bacillus thuringiensis isolates. Applied and Environmental Microbiology, vol. 55, no. 10, p. 2437-2442.

MARTÍNEZ, C. and CABALLERO, P. 2002. Contents of cry genes and insecticidal toxicity of Bacillus thuringiensis strains from terrestrial and aquatic habitats. J. Appl. Microbiol., vol. 92, no. 4 , p. $745-752$.

MARTÍNEZ, C., IBARRA, JE. and CABALLERO, P., 2005. Association analysis between serotype, Cry gene content, and toxicity to Helicoverpa armigera larvae among Bacillus thuringiensis isolates native to Spain. Journal of Invertebrate Pathology, vol. 90, no. 2, p. 91-97.

MARTINS, ES., PRAÇA, LB., DUMAS, VF., SILVA-WERNECK, JO., SONE, EH., WAGA, IC., BERRY, C. and MONNERAT, RG., 2007. Characterization of Bacillus thuringiensis isolates toxic to cotton boll weevil (Anthonomus grandis). Biological Control, vol. 40 , no. 1, p. 65-68.

MEDEIROS, PT., FERREIRA, MN., MARTINS, ES., GOMES, ACMM., FALCÃO, R., DIAS, JMCS. and MONNERAT, RM., 2005. Seleção e caracterização de estirpes de Bacillus thuringiensis efetivas para o controle da traça das crucíferas Plutella xylostella. Pesquisa Agropecuária Brasileira, vol. 40, no. 11 , p. $1145-1148$.

MOHAMMEDI, S., SUBRAMANIAN, SB., YAN, S., TYAGI, RD. and VALÉRO, JR., 2006. Molecular screening of B. thuringiensis strains from wastewater sludge for biopesticide production. Process Biochemistry, vol. 41, no. 4, p. 829-835.

MONNERAT, RG., SANTOS, RC., BARROS, PC., BATISTA, AC. and BERRY, C., 2002. Isolamento e caracterização de estirpes de Bacillus thuringiensis endofíticas do algodão. Brasília: Embrapa. 4 p. Circular técnica, n. 10.

OHGUSHI, A., SAITOH, H., WASANO, N., UEMORI, A. and OHBA, M., 2005. Cloning and characterization of two novel genes, Cry 24B and s1orf2, from mosquitocidal strain of Bacillus thuringiensis serovar sotto. Current Microbiology, vol. 51, no. 2, p. 131-136.

PARRA, JRP., 2001. Técnicas de criação de insetos para programas de controle biológico. $6^{\text {th }}$ ed. Piracicaba: FEALQ. $134 \mathrm{p}$. 
PINTO, LMN. and FIUZA, LM., 2003. Distribuição de genes Cry de Bacillus thuringiensis isolados de solos do Estado do Rio Grande do Sul, Brasil. Ciência Rural, vol. 33, no. 4, p. 699-702.

PINTO, LMN., AZAMBUJA, AO., DIEHL, E. and FIUZA, LM., 2003. Pathogenicity of $B$. thuringiensis isolated from two species of Acromyrmex (Hymenoptera: Formicidae). Brazilian Journal of Biology, v. 63, no. 2, p. 301-306.

PORCAR, M. and CABALLERO, P., 2000. Molecular and insecticidal characterization of a Bacillus thuringiensis strain isolated during a natural epizootic. Jounal Applied Microbiology, vol. 89 , no. 2 , p. 309-316.

PRAÇA, LB., BATISTA, AC., MARTINS, ES., SIQUEIRA, CB., DIAS, DGS., GOMES, ACMM., FALCÃO, R. and MONNERAT, RG. 2004. Estirpes de Bacillus thuringiensis efetivas contra insetos das ordens Lepidoptera, Coleoptera e Diptera. Pesquisa Agropecuária Brasileira, vol. 39, no. 1, p. 11-16.

QUESADA-MORAGA, E., GARCIA-TOVAR, E., VALVERDEGARCIA, P. and SANTIAGO-ALVAREZ, C., 2004. Isolation, geographical diversity and insecticidal activity of Bacillus thuringiensis from soils in Spain. Microbiological Research, vol. 159 , no. 1 , p. $59-71$.

SAADOUN, I., AL-MONAMI, F., OBEIDAT, M., MEQDAM, M. and ELBETIEHA, A., 2001. Assessment of toxic potencial of local Jordanian B. thuringiensis strains on Drosophila melanogaster and Culex sp. (Diptera). Jounal Applied Microbiology, vol. 90, no. 6 , p. 866-872.
SCHNEPF, E., CRICKMORE, N., RIE, J. van, LERECLUS, D., BAUM, J. FEITELSON, J., ZEIGLER, DR. and DEAN, DH., 1998. Bacillus thuringiensis and its pesticidal crystal proteins. Microbiology and Molecular Biology Review, vol. 62, no. 3, p. $775-806$

SILVA, SMB., SILVA-WERNECK, JO., FALCÃO, R., GOMES, AC., FRAGOSO, RR., QUEZADO, MT., OLIVEIRA-NETO, OB., AGUIAR, JB., SÁ, MFG., BRAVO, A. and MONNERAT, RG., 2004. Characterization of novel Brazilian Bacillus thuringiensis strains active against $S$. frugiperda and other insects pests. Journal of Applied Entomology, vol. 128, no. 2, p. 102-107.

SILVA-WERNECK, JO. and MONNERAT, RG., 2001. Metodologias para caracterização de isolados de Bacillus thuringiensis. Brasília: Embrapa Recursos Genéticos e Biotecnologia. 4 p. Circular técnica 10.

TOKCAER, Z., BAYRAKTAR, E., MEHMETOGLU, U., OZCENGIZ, G. and ALAEDDINOGLU, NG. 2006. Response surface optimization of antidipteran delta-endotoxin production by B. thuringiensis subsp. israelensis HD 500. Process Biochemistry, vol. 41 , no. 2 , p. $350-355$.

URIBE, D., MARINEZ, W. and CERÓN, J., 2003. Distribution and diversity of cry genes in native strains of Bacillus thuringiensis obtained from different ecosystems from Columbia. Journal of Invertebrate Pathology, vol. 82, no. 2. p. 119-127.

World Health Organization - WHO, 1985. Informal consultation the development of Bacillus sphaericus as a microbial larvicide. Geneva: UNDP/World Bank/ WHO. 24 p. (Special Programme for Research and Training in Tropical Diseases - TDR). 